\title{
The Application of the Peabody Picture Vocabulary Test - Revised (PPVT-R) to Non-Mainstream Children
}

\begin{tabular}{c|c} 
Erna Alant, D.Phil (Pretoria) \\
S.M. Beukes, MA (Pretoria) \\
Department of Speech Pathology and Audiology, \\
University of Pretoria.
\end{tabular}

\section{ABSTRACT}

This article focuses on the difficulties involved in diagnosing the communication of non-mainstream speakers within a South African context. Various alternatives are discussed, whereby tests can be made more relevant to this population. The revised version of the Peabody Picture Vocabulary Test is applied to a group of Afrikaans-dialect speaking Coloured children in order to determine the merits of standardizing the test for this population. The test results are correlated with the accuracy scores on a story. The findings indicate the feasibility of the standardization of the PPVT-R for this population.

\section{OPSOMMING}

Die problematiek verbonde aan die diagnosering van nie-standaarsprekers se kommunikasie in 'n Suider-Afrikaanse konteks word onder die loep geneem. Verskeie alsernatiewe benaderings waardeur die relevansie van toetse verhoog kan word, word bespreek. Die hersiene weergawe van die Peabody Picture Vocabulary Test is op 'n groep nie-standaard Afrikaanssprekende Kleurling kinders toegepas ten einde die meriete van toetsstandaardisasie vir hierdie teikengroep te bepaal. Die toetsresultate word met die akkuraatheidstellings van ' $n$ storie gekorreleer. Die bevindings dui daarop dat standaardisasie van die PPVT-R vir hierdie populasie uitvoerbaar is. 
The difficulties involved in diagnosing the communication problems of the client speaking a non-standard or non-mainstream language have recently received much attention from speech and language pathologists (Musselwhite, 1983; Wiener, Lewnau and Erway, 1983; Terrel and Terrel, 1983). The reason for this widespread interest stems from the realization that very few reliable diagnostic tools are available for the evaluation of communication of non-standard-language speakers (Saville-Troike, 1973). Various authors (Erickson and Omark, 198I; Terrel and Terrel, 1983; Adler \& Birdsong, 1983) have expressed their concern with the effect that misdiagnosis (i.e. overcompensation or undercompensation for the language variety) could have on the client in terms of the provision of adequate clinical services.

A result of the current awareness of 'culturally fair' or 'non-biased' testing is the active search for alternative ways of enhancing diagnostic procedures. The functional approach to diagnosis has become prominent within this context in view of the current psycholinguistic and sociolinguistic theory (Erickson and Omark, 1981). The emphasis is on the child's natural communication, and contextual evaluations of interactive abilities are advocated. The value of tests as a supplement to functional assessments is stressed, as an integrated diagnosis essentially involves gaining information from more than one source.

It is against this background that the limitations of traditional speech therapy tests for use with different populations are recognized and efforts are made to reduce or eliminate the cultural and socio-economic biases in these tests. The revision of the Peabody Picture Vocabulary Test (Dunn \& Dunn, 1981) as well as the translation of the Auditory Comprehension of Language (Carrow-Woolfolk, 1973) are examples of test adaptations aimed at facilitating diagnosis with different groups. The PPVT is described as 'culturally specific' and has a fault factor of at least three years according to Taylor (1977), but the revised version has eliminated many of these cultural biases (Adler and Birdsong, 1983).

In a recent article, Vaughn-Cooke (1983) discusses various ways in which tests can be modified or adapted for use with different groups, although each of these alternatives pose their own problems. The most uncomplicated procedure would be to standardize existing tests for use with a particular group. This approach could, however, lead to the difficulty of coping with 'low norms' in comparison with other groups.

A second possibility would be the inclusion of a small percentage of minorities in the standardization sample, as was done in the revised Peabody Picture Vocabulary Test (PPVT-R). Appropriate representation of a particular group could, however, still be a problem in that only a small percentage of minorities can be included in the standardization sample.

A third alternative involves the modification of existing tests in order to make them appropriate for non-mainstream speakers. The difficulties entailed in the modification or revision of tests include inherent problems in providing a comparable form and content of the items that are being changed in order to adhere to the criteria of the original test (Saville-Troike, 1973; Labov, 1972).

Another possibility would be to develop a new test for use with different groups. Although perhaps the most relevant alternative, it is not always practical as expertise and substantial financial assistance is required for the standardization and development of a new test.

The last alternative described by Vaughn-Cooke (1983) is the use of non-standardized language samples and criterion reference measures, as previously discussed. The lack of norms in these evaluations, however, complicates the differentiation between language pathology and the rules of non-standard language. The need for norm referenced techniques in the evaluation process is therefore explicit. Vaughn-Cooke (1983: 33) concludes his review on a rather pessimistic note: "It is not an overstatement to say that a crisis exists in the area of assessment for non-mainstream speakers. Researchers, clinicians and test developers must intensify their efforts to overcome this crisis and meet the need of diagnosticians. Diagnosticians do not need more evaluations of the assessment problem, nor do they need more 'interim' solutions. They need valid, reliable assessment tools."

The diversity of the South African population emphasizes the relevance of the above statement to speech and language therapists working in this country. Not only do therapists lack standardized communication assessment tools, but also descriptions of what constitutes a particular dialect or language variation. The differentiation between language differences and language pathology is further complicated for the therapist working in the Afrikaans speech community because relatively little information is available as regards the characteristics, rules and functions of the varieties/dialects of Afrikaans (Webb, 1984).

A sociolinguistic approach in determining the appropriacy of language use would assume that language is a social phenomenon (Bartsch, 1982) which is to a large extent context sensitive and nom determined. The vernacular which the children in this study used is a non-standard variety of Afrikaans with a set of rules and norms that differs from that of Standard Afrikaans in some respects. Although geographically in close proximity to other Afrikaans-speaking communities, this community is almost completely isolated from other Afrikaans-speaking communities. Sections of Eersterust community are dialect speakers of Afrikaans, including the lower socio-economic strata of this group which are particularly isolated from the greater Afrikaansspeaking community. This isolation was confirmed in conversation with Eersterust teachers who stated that many of the preschool children from the area where the research was conducted had never been outside their suburb.

In view of the above, this study aims to develop a diagnostic tool for the evaluation of the receptive vocabulary of this community A provisional translation of the PPVT- $R$ into Standard Afrikaans was used as a basis for test modifications and adaptations to fit the needs of the community.

As the PPVT-R was standardized on a sample that included minority speakers, it seemed to provide a logical starting point from which further research could be undertaken. Although the revised edition had succeeded in eliminating many of the cultural biases, a translation of the test would not necessarily guarantee the same results. The aim of the research therefore centered around the appropriateness of the test items for this particular group of children.

The choice of the PPVT-R was further enhanced by the exposure that the test has had in research and translations in other parts of the world (Cox and Jones, 1985). This contributed towards giving a more realistic idea of the difficulties that would be encountered when dealing with this test.

Apart fom qualitative analyses of the PPVT-R done in order to determine appropriacy of test material, the results were compared with receptive language scores obtained from another informal language assessment situation (refer Appendix 2). As the PPVT-R 
is a test of receptive vocabulary it was hypothesized that both these tests should demonstrate some overlap in the ability being assessed.

Although no attempt could be made to validate the PPVT-R in this context, an association between these two measurements could indicate some potential in the use of these evaluation techniques with this population.

\section{METHOD}

The 77 children included in the study were prospective schoolbeginners in the next year at Nantes Primary School in Eersterust. Twenty-four of these children had attended a preschool class at Nantes Primary School for six months, while the rest of the children had no pre-school experience.

The latter were recruited through children attending Nantes Primary School who were requested to provide the names of relatives, friends and acquaintances who intended enrolling at the school in the following year. All those named by the children were included in the study. Only children attending this particular school were tested as one of the aims was to conduct a longitudinal study whereby the same children would be evaluated at the end of their first school year.

The children tested all came from the Nantes area, which is one of the more deprived areas in Eersterust. Questionnaires were sent out to the parents of the children to determine their occupations and educational levels and the size of households as a measure of socio-economic status.

The age of the children varied between 5,5 and 6,5 with the majority of the children between 5,5 and 6,0 years. All the children in the sample were Afrikaans-speaking. The influence of English in this area is relatively small as it is a predominantly Afrikaansspeaking community. Table I gives a more specific description of the subjects used in the study.

Table 1: Description of subjects

\begin{tabular}{|l|l|}
\hline Variable & Description \\
\hline Age & $\frac{1}{\mathrm{x}}=5,5$ (SD:0,61) \\
\hline Sex $;$ & \\
male & 38 \\
female & 39 \\
\hline Educational level & \\
mother & $\bar{x} \pm 7,05$ (SD:1,39) \\
father & $\frac{1}{\mathrm{x}}=7,98$ (SD: 1,64 \\
\hline $\begin{array}{l}\text { Pre-school training experience } \\
\text { none }\end{array}$ \\
6 months & 53 \\
\hline Audiological screeening & 24 \\
passed both tests & 62 \\
failed both tests & 15 \\
\hline Size of households & $\bar{x}=5,73$ (SD:2,49) \\
\hline
\end{tabular}

\section{MATERIALS}

The PPVT-R was translated by members of the Eersterus-Project of the Department of Speech Therapy and Audiology at the University of Pretoria which consisted of speech therapists and a linguist. Care was taken to keep the Standard Afrikaans word as close as possible to the original Standard English with respect to semantic characteristics and difficulty and in terms of the visual clues of each test item.

The Peabody Picture Vocabulary Tests-Revised (PPVT-R) was provisionally translated into Standard Afrikaans (Appendix I) to determine whether there would be any merit in standardizing the test for Coloured children, particularly in view of the pictures, and concepts, used. The use of the PPVT's existing norms and IQ scores would be evaluated in terms of their appropriacy for this group. The children's performance on the Afrikaans PPVT-R would then be correlated with the scores obtained from a comprehension story in order to compare achievements on different measuring techniques.

The comprehension story used was that of the 'fox and the crab' (Berry, 1969). This story was modified by Alant (1984) for use with five and a half year olds in a comprehension situation.

The story was lengthened for the purpose of testing by means of including more characters (factual material), while maintaining the basic story together with the inferences required to complete the ending. The story was recorded on video tape (with facial cues and gestures only in order to simulate stories or narratives occurring in normal communication). A nursery school teacher as well as the teachers of the beginners classes at the school were asked to view the tape and to evaluate it in terms of its appropriacy in terms of:

- Middle class biases to vocabulary and language structures; - Cultural prejudice and content;

- Age appropriacy.

Some minor changes were suggested after which the story was rerecorded for use in the pilot and main study.

\section{PROCEDURE}

The children were occupied in a classroom where they were provided with toys and snacks. This gave the researchers the opportunity to familiarize themselves with the subjects before testing. Each child was tested individually and sent home or to the pre-school class after the testing was completed.

Each was tested on the provisional translation of the PPVT-R. The prescribed procedure was used for the application of the PPVT-R. When, however, the child pointed to the wrong picture, the following procedure was used in order to determine whether the child responded incorrectly because he did not know the 'word' or because he did not understand the concept represented by the particular item.

\section{For eg.}

Step 1: Show me...

If wrong, then step 2

Step 2: What is this? (Researcher points to any other picture in order to avoid repetition of therapist's stimulus utterance).

Step 3: What is this? (Researcher points to the target picture. The verbalization of the subjects was written down).

The children also observed a pre-recorded video-taped story ( 4 minutes) after which some comprehension questions were asked based on the story. Each child was tested individually and probing was used in order to facilitate the answering of the questions, (Alant, 1984).

\section{THE TEST SITUATION}

All the children were tested in the same classroom of the school. Although every possible effort was made to provide a pleasant atmosphere for the children, this more formal situation could have been threatening to some of them, particularly those children who had no pre-school experience (Saville-Troike, 1973). The use of researchers that were not from the area could also have influenced the children's behaviour (Labov, 1972; Adler \& Birdsong, 1983). However, the lack of suitably qualified people from the area necessitated a compromise in this regard (Musselwhite, 1983; Erickson \& Omark, 1981). 


\section{DATA ANALYSIS}

Peabody Picture Vocabulary Test - Revised: the PPVT-R results were scored according to the manual of the test. Only the raw scores were used in the analysis as the norms were not suitable for use with this population (Taylor, 1977). The raw scores of the PPVT-R were then correlated with the findings of the responses to the questions asked on the comprehension story. All the error items were noted and the children's responses to the items were qualitatively analysed.

ACCURACY OF THE ANSWERS TO COMPREHENSION QUESTIONS: Four questions were asked, based on the story. These questions were ranked from easy to difficult i.e. from questions demanding immediate reproduction of facts to questions relating to answers based on inferences drawn from the story. The grading of the questions was first tested in Alant (1984) and proved to be satisfactory in that the last questions were more demanding than those which preceded them. This was deemed important as easy questions could be motivating in the beginning of the interaction (refer Appendix 2).

PROBING: Probing was used in order to prevent inhibited children being discredited for lack of understanding. Although the effectiveness of probing with these children could be questioned (Labov, 1972; Faeggans and Farran, 1982) in view of their unfamilia rity with the context and communication situation, reinforcement of verbalizations could contribute to an increase of verbal behaviour (Bolton, 1979). A probe was defined as a verbalization from the therapist. followed by a pause during which the child was allowed the opportunity to respond. Probing was used when children did not respond or when they responded with 'don't know' or other short replies. Non-directive probing was used at first followed by more direct probes depending on how many probes were necessary (refer Appendix 2).

\section{STATISTICAL ANALYSIS}

Descriptive statistics were used in order to examine the children's general performance on the PPVT-R and comprehension questions after which a qualitative description of errors was made. Correlation coefficients were calculated to obtain a measure of association between the accuracy of responses and the PPVT-R (translated) for various levels of probing.

\section{RESULTS AND DISCUSSION}

Figure 1 reflects the general performance (raw scores) of the subjects on the PPVT-R (translated) and Table 2 gives the mean and standard deviations for the group.

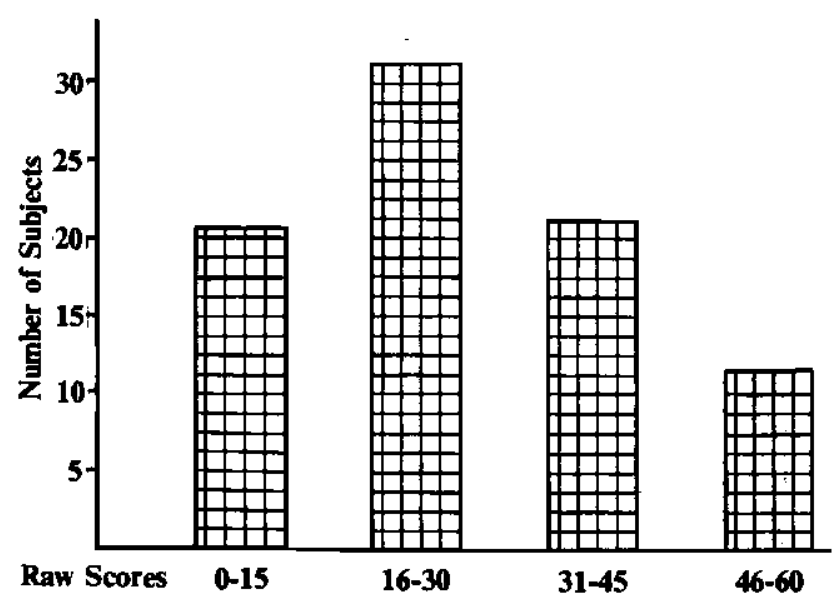

Figure 1: Frequency bar chart of the children's performance on the PPVT-R (Afrikaans translation)
Table 2: Descriptive statistics of the group's performance on the PPVT-R (Afrikaans translation).

\begin{tabular}{lccccc}
\hline & Mean & SD & \multicolumn{3}{c}{ Min Value Max Value of mean } \\
\hline $\begin{array}{l}\text { PPVT-R } \\
\text { (raw }\end{array}$ & 25,73 & 13,15 & 7,00 & 59,00 & 1,50 \\
scores) & & & & & \\
\hline
\end{tabular}

From the above figure and table it is clear that the children obtained low raw scores on the PPVT-R, particularly in view of the required raw score of \pm 62 stipulated for their age according to the American norms (Dunn \& Dunn, 1981).

Vaughn-Cooke's (1983) concern about the standardization of tests on different populations due to the problem of low norms seems to be relevant in the present study. The low scores on the test necessitate a qualitative analysis of the errors in order to determine the relevancy of the test items for this particular group of children. Table 3 gives some indication of the common errors made on the first 25 items (the mean score for this group) while Table 4 illustrates interesting differences between the children with and without pre-school training experience.

Table 3: Common responses on some of the first 25 items.

\begin{tabular}{|c|c|l|}
\hline Item & $\%$ Correct & \multicolumn{1}{|c|}{ Type of Response } \\
\hline 8: band (tyre) & 37 & wiel (wheel) 37\%, tyre 26\% \\
9: koei (cow) & 61 & bees (beast) 11\% \\
10: lamp (lamp) & 59 & lig (light) 33\%, globe 3\% \\
15: verband (bandage) & 62 & voet (foot) 20\%, bandage 4\% \\
18: heining (fence) & 33 & hek (gate) 19\%, planke (planks) \\
22: seil (sail) & 36 & lo\%, fence 6\% \\
& & skip (ship) 36\%, (om te) ry \\
& (to ride) 10\% \\
\hline
\end{tabular}

Tables 3 and 4 clearly demonstrate the statement of Leeman (1981) that direct translation of test items is problematic because of the different ways in which experience is conceptualized in different cultures and expressed in different dialects/languages. In spite of the revision of the PPVT-R to eliminate cultural biases, it is clear that many of the first 25 items of the provisional translation are biased against these non-mainstream dialectspeaking children. These items contain information and represent concepts that have little relevance to their dialect, culture and socio-economic status.

Item 18 shows that the word heining is relatively unknown to these children. Many different responses to this item were recorded, ranging from hek (gate), planke (planks), fence, jaartdraad (yard fence) to stokke (sticks). The variety of lexical items used by these children suggests that the concept of a picket fence is unknown to them. Further empirical investigation is necessary to determine what the dialect vocabulary item for fence is.

Another example in this regard is item 22 (om te) seil(sail) which is pictorially represented by a small sailing-vessel on water. The responses to this picture indicate that the vessel was recognized as a "ship", but that the function of the vessel as expressed in the verb is unknown to them. Once again this can be seen as a result of their socio-economic status in that this item reflects information concerning a luxury of middle class lifestyle that goes beyond their immediate experience.

The South African Joumal of Communication Disorders, Vol. 33, 1986 
The Application of the Revised Version of the Peabody Picture Vocabulary Test (PPVT-R) to Non-Mainstream Children

Table 4: Interesting differences in some responses between children with preschool training and children with no pre-school training.

\begin{tabular}{|l|c|l|l|l|}
\hline & \multicolumn{2}{|c|}{ Children with pre-school training } & \multicolumn{2}{c|}{ Children with no pre-school training } \\
\hline \multicolumn{1}{|c|}{ Item } & $\%$ Correct & Type of Response & $\%$ Correct & Type of Response \\
\hline 14: elmboog (elbow) & 88 & hand 8\%, arm 4\% & 60 & hand $40 \%$ \\
16: veer (feather) & 100 & - & 82 & blaar (leaf) $10 \%$ \\
17: leeg (empty) & 80 & glas (glass) 12\%, koppie (cup) 8\% & 62 & koppie (cup) 26\%, glas (glass) 11\% \\
19: ongeluk (accident) & 96 & kar(re) (cars) 4\% & 64 & kar(re) (cars) 16\% \\
26: gereedskap (tool) & 60 & spanner 20\% & 47 & spanner 30\% \\
27: vierkant (square) & 100 & - & 47 & blokkie (block) $24 \%$ \\
32: koevert (envelope) & 84 & brief (letter) 16\% & 62 & brief (letter) 38\% \\
49: kraan (faucet) & 100 & - & 60 & pomp (pump) 40\% \\
\hline
\end{tabular}

The same argument holds in the case of item 10 where one third of the children were not able to connect the word lamp (lamp) with the pictorial representation. Lig (light) was used as the appropriate lexical item in their dialect, although responses such as blomding (flower thing), glas (glass) and globe were also recorded. The deprived background of these children is presumably again the reason for the high frequency of lig. Lig is a generic term for any electrical light appliance. These children obviously do not need to make distinctions between sophisticated electrical appliances.

Some significant differences occurred between those children who had pre-school training and those who had no pre-school training. The pre-school group exhibited a greater sensitivity for the Standard Afrikaans word than did the other group. This is presumably the result of exposure to the standard language variety in the formal school situation. More pre-schoolers for example knew the word gereedskap (tool) (item 26) and all of them knew the word kraan (faucet, tap) (item 49) as opposed to the other group of whom $40 \%$ used the word pomp (pump). Once again socio-economic factors cannot be ignored here. The pictorial representation of this item shows a modern mixer-type bathroom tap of which these children presumably have little or no experience.<smiles>C1CCCCC1</smiles>

One must bear in mind that these interesting differences reflect a greater knowledge of sociolinguistic norms on the part of the preschool group. As Coetzee (1982) points out there are very few members of a speech community who know only their own dialect. The children without pre-school training presumably had less exposure to Standard Afrikaans which is reflected in their responses. They show a marked lack of sensitivity in comparison with the pre-school group who have had a greater exposure to standard norms. In other words these pre-schoolers' responses demonstrate their ability to choose between items from their dialect and the standard language. They demonstrate an awareness of the appropriate sociolinguistic norms in a specific diglossic context.

In view of the errors made on this test in Standard Afrikaans by these dialect-speaking children, it is evident that a sociolinguistic approach is needed in compiling a revised translation for use within this specific group. A sociolinguistic dimension to compiling these test items would imply careful consideration of not only the linguistic form but also of the status of certain items in a particular speech community.

To modify an existing test implies that the modified version has to adhere to the same underlying principles in the selection of items as the original test i.e. level of abstraction and nature of visual clues. This requirement necessitates a sociolinguistic approach in order to improve the reliability and in particular the validity of the test.

In the last instance, the children's PPVT-R scores were compared with their performance on the comprehension questions (Table $5)$.

Categories were not analysed when there were fewer than 10 cases per category, accounting for the absence of the other probing scores on the different questions. From Table 5 it is evident that the PPVT-R scores correlated significantly with the accuracy of the responses on all the questions indicating a strong positive association between these two variables.

This positive correlation suggests some common denominator between these two tests, although it could not be seen as a validation of the procedures as both these measurements evaluate different aspects of language (Culatta, Page and Ellis, 1983). The correlation between these two tests could, however, be regarded as a positive indication for future standardization of the PPVT-R for this group of children.

The findings of this study confirm the difficulties involved in the modification of existing tests in order to reduce or eliminate cultural biases. However, results indicate the feasibility of the standardization of the PPVT-R for this population. Such standardization would involve the development of appropriate test items as well as the creation of local norms of this population (Adler and Birdsong, 1983) in order to facilitate continued assessment of children in the area.

Table 5: Partial correlation between PPVT-R scores and accuracy of comprehension questions when probing is held constant.

\begin{tabular}{|l|l|c|}
\hline Question & Probing level & Probability of Exceedence \\
\hline Question 1 & Probing 1 & 0,0189 \\
Question 2 & Probing 1 & 0,0474 \\
& Probing 2 & 0,0009 \\
& Probing 3 & 0,0056 \\
Question 3 & Probing 1 & 0,0041 \\
& Probing 2 & 0,0079 \\
Question 4 & Probing 1 & 0,0001 \\
\hline
\end{tabular}




\section{ACKNOWLEDGEMENTS}

This research is part of the Eersterust-Project of the Department of Speech Therapy and Audiology at the University of Pretoria. The financial support of the University of Pretoria, the enthusiastic participation of the members of the research team as well as the dedicated assistance of the teachers and children at the school is hereby acknowledged.

\section{REFERENCES}

Adler, S. and Birdsong, S. Reliability and validity of standardized testing tools used with poor children. Topics in Language Disorders, 3, 3, 76-87, 1983.

Alant, E. The development of a procedure for analysing communication of pre-school children. Unpublished D.Phil Thesis, Depart. Speech Therapy and Audiology, University of Pretoria, Pretoria, 1984.

Bartsch, R. The concepts 'rule' and 'norm' in linguistics. In Lingua, 58, 51-81, 1982.

Berry, M.. Language disorders of children. Englewood-Cliffs, Prentice-Hall, 1969.

Bolton, R. People skills. Englewood-Cliffs, Prentice-Hall, 1979.

Carrow-Woolfolk, E. Test for auditory comprehension of Language. New York: Teaching Resources, 1973.

Coetzee, A.E. 'n Heroriëntering van die begrip standaardtaal en 'n voorstudie van die ontwikkeling van Standaard-Afrikaans gedurende die 20e eeu. In Tydskrif vir Geestewetenskappe, 22, 4, 271-289, 1982.

Cox, T. and Jones, G. Disadvantaged 11 year olds, Oxford: Pergamon Press, 1985.

Culatta, B., Page, J.L. and Ellis, J. Story retelling as a communicative performance screening tool. Language, Speech and Hearing Services in Schools, 14, 2, 66-74, 1983.

Dunn, L.M. and Dunn, L.M. Peabody Picture Vocabulary Test - Revised. American Guidance Services, Circle Pines, 1981.

Erickson, J.G. and Omark, D.R. Communication Assessment of the bilingual bicultural child, Baltimore, University Park Press, 1981.

Faegans, L. Farran, D.C. The Language of Children reared in Poverty, New York: Academic Press, 1982.

Labov, W. The Logic of Non-standard English. In Giglioli, P. (ed), Language and Social Context, New York: Penguin, 1972.

Leeman, E.M. Evaluating Language Assessment Tests. In Erickson, J.G. and D.R. Omark (eds.): Communication Assessment of the Bilingual Bicultural Child, 115-128, 1981.

Musselwhite, C.R. Pluralistic Assessment in Speech-Language Pathology: Use of dual norms in the Placement process. Language, Speech and Hearing Services in Schools, 14, 1, 29-38, 1983.

Saville-Troike, M. Bilingual Education Series: 2, Arlington: Center for Applied Linguistics, 1973.

Taylor, $\mathrm{O}$. The sociolinguistic dimension in standardized testing. In Saville-Troike, M. (ed.), Linguistics and Anthropology, Washington, D.C.: Georgetown University Press, 1977.

Terrel, S.L. and Terrel, F. Distinguishing linguistic differences from disorders: the past, present and future of non-biased assessment, Topics in Language Disorders, 3, 3, 1-7, 1983.

Vaughn-Cooke, B.F. Improving Language Assessment in Minority Children, $A S H A$, September, 29-33, 1983.

Wiener, F.D., Lewnau, L.E. and Erway, E. Measuring language competency in Speakers of Black American English, $J$. Speech Hear. Disord. 48, 76-84, 1983.

Webb, V.N. Sosiolinguistiek en die spraakterapie. In Beukes, S.M. (ed.): The Role of the Speech Therapist in a Multilingual Society. Symposium Papers. University of Pretoria, Department of Speech Therapy and Audiology, 22-37, 1984.
APPENDIX 1

\section{VOORLOPIGE VERTALING VAN PPVT (REVISED)} IN AFRIKAANS

NAAM VAN TOETSLING:

DATUM VAN TOETS:

\section{NAAM VAN TOETSAFNEMER:}

LYS:

\begin{tabular}{|c|c|c|c|}
\hline \multicolumn{2}{|c|}{ Item $\mathbf{N r}$} & Sleutel & Respons \\
\hline $1 / 23$ & 1 & bus $\ldots \ldots \ldots \ldots \ldots \ldots \ldots$ (4) & \\
\hline & 2 & hand $\ldots \ldots \ldots \ldots \ldots \ldots$ (1) & \\
\hline & 3 & bed $\ldots \ldots \ldots \ldots \ldots \ldots \ldots$ (3) & \\
\hline & 4 & trekker $\ldots \ldots \ldots \ldots \ldots \ldots$ (3) & \\
\hline & 5 & klerekas ............ (1) & \\
\hline & 6 & slang $\ldots \ldots \ldots \ldots \ldots$ (4) & \\
\hline & 7 & skip $\ldots \ldots \ldots \ldots \ldots \ldots \ldots$ (2) & \\
\hline & 8 & band $\ldots \ldots \ldots \ldots \ldots \ldots$ (3) & \\
\hline & 9 & koei $\ldots \ldots \ldots \ldots \ldots \ldots$ (1) & \\
\hline $31 / 2$ & 10 & $\operatorname{lamp} \ldots \ldots \ldots \ldots \ldots \ldots$ & \\
\hline & 11 & drom $\ldots \ldots \ldots \ldots \ldots \ldots$ & \\
\hline & 12 & knie $\ldots \ldots \ldots \ldots \ldots \ldots$ (4) & \\
\hline & 13 & helikopter $\ldots \ldots \ldots \ldots \ldots$ (2) & \\
\hline & 14 & elmboog $\ldots \ldots \ldots \ldots \ldots$ (4) & \\
\hline & 15 & verband $\ldots \ldots \ldots \ldots \ldots$ (4) & \\
\hline & 16 & veer $\ldots \ldots \ldots \ldots \ldots \ldots$ (1) & \\
\hline & 17 & leeg $\ldots \ldots \ldots \ldots \ldots \ldots \ldots$ (3) & \\
\hline & 19 & ongeluk $\ldots \ldots \ldots \ldots \ldots$ (2) & \\
\hline $41 / 2$ & 20 & net $\ldots \ldots \ldots \ldots \ldots \ldots \ldots$ & \\
\hline & 21 & skeur $\ldots \ldots \ldots \ldots \ldots \ldots$ (4) & \\
\hline & 22 & seil $\ldots \ldots \ldots \ldots \ldots \ldots \ldots$ (1) & \\
\hline & 23 & mett............ (2) & \\
\hline & 24 & skil ............. (3) & \\
\hline & 25 & dierehok ............. (1) & \\
\hline & 26 & gereedskap .......... (4) & \\
\hline & 27 & vierkant $\ldots \ldots \ldots \ldots \ldots \ldots$ (4) & \\
\hline & 28 & rek $\ldots \ldots \ldots \ldots \ldots \ldots \ldots$ & \\
\hline & 29 & pyl $\ldots \ldots \ldots \ldots \ldots \ldots \ldots$ (2) & \\
\hline & 30 & vasmaak $\ldots \ldots \ldots \ldots \ldots$ (2) & \\
\hline & 31 & nes $\ldots \ldots \ldots \ldots \ldots \ldots \ldots$ (1) & \\
\hline & 32 & koevert $\ldots \ldots \ldots \ldots \ldots$ (2) & \\
\hline & 33 & hoek............. (3) & \\
\hline & 34 & vasplak ........... (4) & \\
\hline $5^{1 / 2}$ & 35 & streel $\ldots \ldots \ldots \ldots \ldots \ldots$ (1) & \\
\hline & 36 & pikkewyn.......... (1) & $i$ \\
\hline & 37 & vaswerk $\ldots \ldots \ldots \ldots \ldots$ (2) & $\div$ \\
\hline & 38 & aflewer............. (1) & 1 \\
\hline & 39 & duik $\ldots \ldots \ldots \ldots \ldots \ldots \ldots$ & $i$ \\
\hline 6 & 40 & valskerm $\ldots \ldots \ldots \ldots \ldots$ (3) & ! \\
\hline & 41 & wollerig $\ldots \ldots \ldots \ldots \ldots$ (4) & 1 \\
\hline & 42 & groente..$\ldots \ldots \ldots \ldots$ (4) & 1 \\
\hline & 43 & skouer $\ldots \ldots \ldots \ldots \ldots \ldots$ (3) & \\
\hline & 44 & drup.............. (2) & \\
\hline & 45 & klou .............. (4) & \\
\hline & 46 & versier $\ldots \ldots \ldots \ldots \ldots \ldots$ (3) & \\
\hline & 47 & $\operatorname{raam} \ldots \ldots \ldots \ldots \ldots$ (1) & \\
\hline & 48 & bos $\ldots \ldots \ldots \ldots \ldots \ldots \ldots$ & \\
\hline & 49 & kraan...$\ldots \ldots \ldots \ldots$ & \\
\hline $61 / 2$ & 50 & groep $\ldots \ldots \ldots \ldots \ldots \ldots$ & \\
\hline & 51 & stingel $\ldots \ldots \ldots \ldots \ldots \ldots$ (3) & \\
\hline & 52 & blompot $\ldots \ldots \ldots \ldots \ldots$ (3) & \\
\hline & 53 & pedaal $\ldots \ldots \ldots \ldots \ldots \ldots$ (1) & \\
\hline & 54 & kapsule $\ldots \ldots \ldots \ldots \ldots \ldots$ (2) & \\
\hline 7 & 55 & verbaas $\ldots \ldots \ldots \ldots \ldots \ldots$ (4) & \\
\hline & 56 & boombas $\ldots \ldots \ldots \ldots \ldots$ (2) & \\
\hline & 57 & werktuigkundige.$\ldots \ldots \ldots$ (2) & \\
\hline & 58 & tamboeryn ............ (1) & \\
\hline & 59 & teleurstelling $\ldots \ldots \ldots \ldots \ldots$ (4) & \\
\hline & 60 & toeken $\ldots \ldots \ldots \ldots \ldots \ldots$ (3) & \\
\hline & 61 & beker.$\ldots \ldots \ldots \ldots \ldots \ldots$ (3) & \\
\hline
\end{tabular}

The South African Journal of Communication Disorders, Vol. 33, 1986 

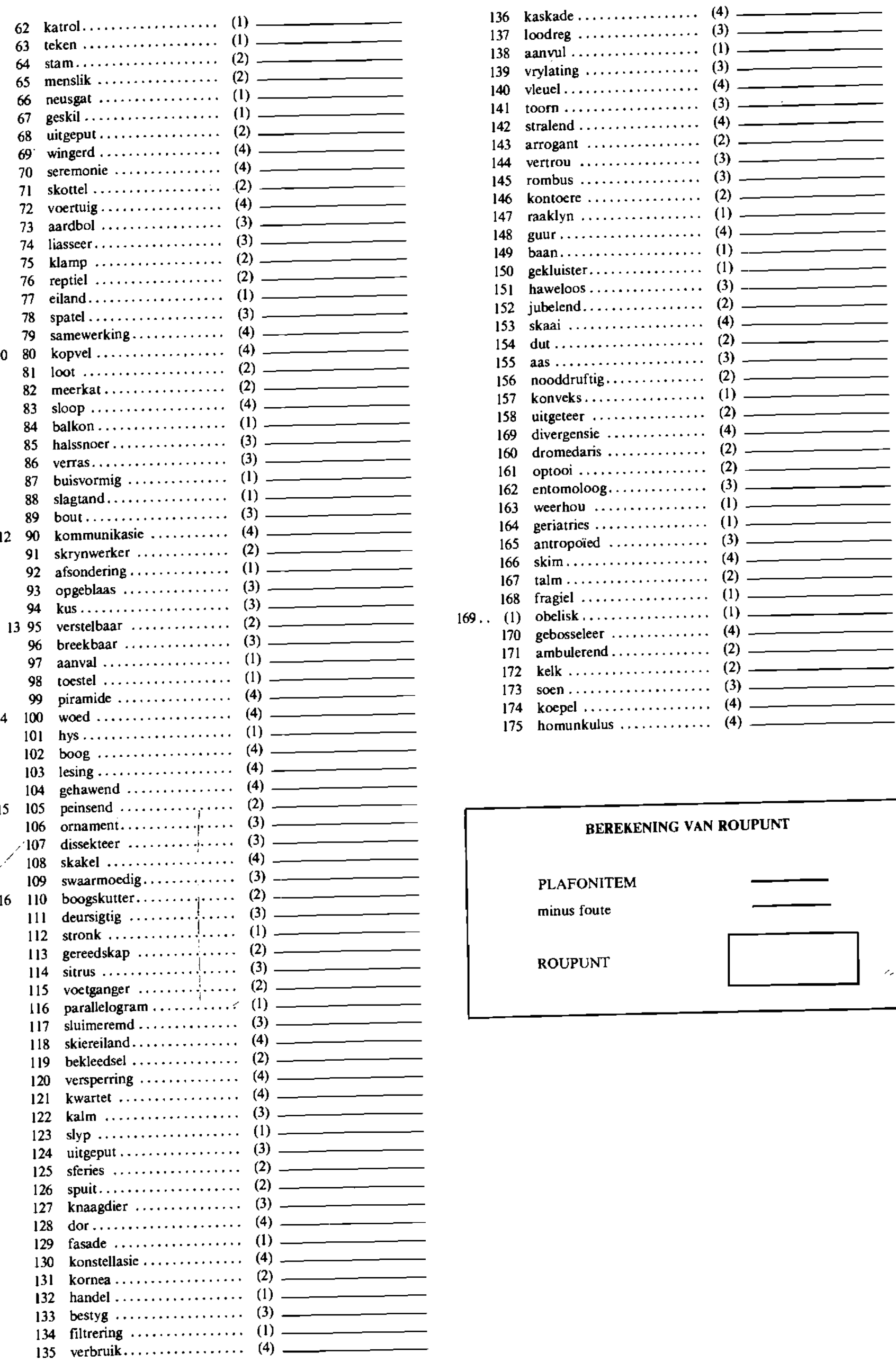

\begin{tabular}{|l|l|}
\hline \multicolumn{2}{|c|}{ REREKENING VAN ROUPUNT } \\
$\begin{array}{l}\text { PLAFONITEM } \\
\text { minus foute }\end{array}$ \\
ROUPUNT
\end{tabular}




\section{APPENDIX 2}

STORY

\section{Unit 1}

E.3

Eendag// stap ou jakkals in die bos./ Hy loop en spog te lekker, / want $k y$ kan tog $S O$ : vinnig hardloop.// Toe hy nog so stap, sien hy vir olifant onder die boom staan.// "Goeie Môre OU olifant" sê jakkals./ "Kom ons hardloop reisies, dan kyk O:NS wie van ons twee hardloop die vinnigste." // Ou olifant dink toe so 'n bietjie en sê toe "Agge nee ou jakkals jy is gans te vinnig vir MY."/ Ou jakkals lag te lekker./ "Ja ou olifant, ek sal jou sommer vê:r wen."// En so stap jakkals toe aan.//

\section{Unit 2}

Toe jakkals nog so stap/ sien hy vir skilpad./ "Goeie Môre skilpad./ Kom ons hardloop reisies dan kyk ons wie van ons twee is die vinnigste."/ Skilpad dink toe so 'n bietjie/ en sê: "Agge nee ou jakkals jy is gans te vinnig vir My."// Ou jakkals lag te lekker. Dis tog te lekker vir hom om te weet dat al die diere te bang is om teen hom reiseis te hardloop.// En so stap jakkals toe aan . . .//

\section{Unit 3}

Toe jakkals nog so stap, sien hy vir krap op die grond $/ /$ "Goeie môre ou krap. Kom ons hardloop reisies, dan kyk ons wie van ons twee is die vinnigste."/ / Ou krap dink toe so 'n bietjie . . / / en toe kry hy'n baie Goeie plan. " Goed ou jakkals, kom ons hardloop reisies dan kyk ons wie van ons twee is die vinnigste."//Ou jakkals is stom geslaan./ Hy kan nie glo dat krap teen hom wil reisies hardoop nie.//

\section{Unit 4}

Die twee begin toe hardloop./MAAR net toe jakkals begin hardloop, spring krap op jakkals se stert en Kl:ou daar vas./ Jakkals hardloop baie vinnig tot by die wenpaal./En toe hy by die wenpaal kom/ skud hy sy stert en kyk om om te sien waar die krap is.// Huuu . . . en daar sien jakkals vir $\mathrm{krap} O P$ DIE GROND! " $\mathrm{Ag} O u$ jakkals," sê die krap toe "Ek wag al lankal hier vir jou op die grond."

\section{VERBAL ANALYSES:}

\section{Accuracy:}

Question 1: Who walked in the veld?

$$
\begin{aligned}
& 4=\text { Fox } \\
& 3=\text { Description of animal, no name } \\
& 2=\text { Wrong animal } \\
& 1=\text { No response/did not understand }
\end{aligned}
$$

Question 2: Whom did he meet there?

$$
\begin{aligned}
& 4=\text { All three correct } \\
& 3=\text { Two correct } \\
& 2=\text { One correct } \\
& 1=\text { None correct }
\end{aligned}
$$

Question 3: What was the clever plan of the crab?

$4=$ Indication of relationship between action and intention

$3=$ Repeat actions involved e.g. jumped onto tail and clung onto it

$2=$ Partially correct repetition of actions e.g. hanged on tail

$1=$ No response/Response out of context/Do not know

Question 4: Who do you think won the race and why? The WHY part of the question is scored only: $4=$ In context explanation e.g. crab won because he made a clever plan

$3=$ In context, but concrete e.g. crab, because he jumped on the fox's tail

$2=$ Vague, out of context e.g. fox, because he is faster

$I=$ No response/Do not understand/Do not know

\section{PROBING ANALYSES:}

All the probes on each question were calculated and categorized according to the following scoring system:

$1=0-5$ probes

$2=6-10$ probes

$\mathbf{S}=$ Smile

$\mathrm{E}=$ Eye widening/ Eye narrowing

$\mathbf{F}=$ Frowning

$\mathrm{HN}=$ Head nod

HS $=$ Head shake

$\mathrm{IL}=$ Illustration

Italics $=$ Emphasized

\section{CAPITAL LETTERS $=$ STRESSED with more LOUDNESS}

SO: $=$ The last sound prolonged

$/=$ Pause (untimed duration shown by number of $/ /$

$/ /$ = Longer pause 